
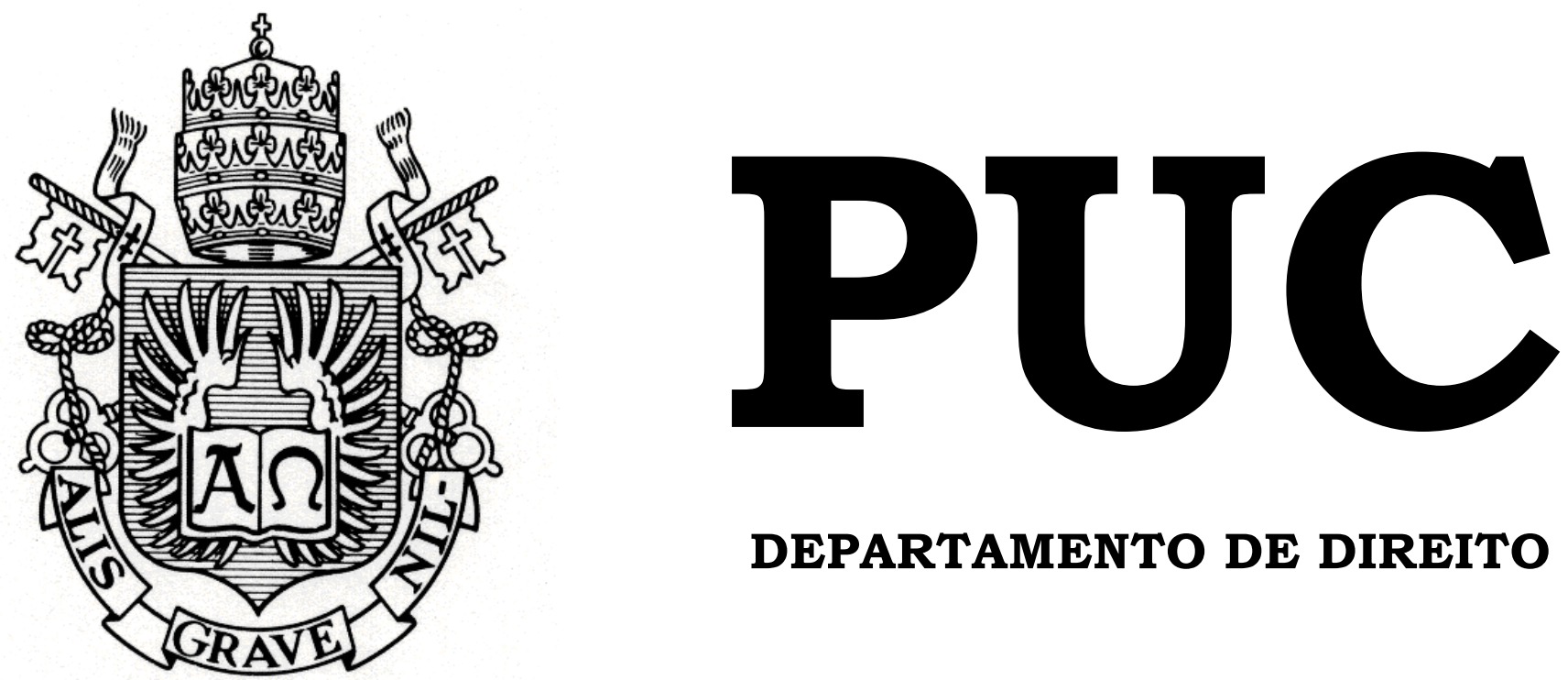

DEPARTAMENTO DE DIREITO

\title{
Ofícios de Alerta na Comissão de Valores Mobiliários
}

por

Paula Leonette Rangel

ORIENTADORA: Norma Jonssen Parente

2015.1

PONTIFÍCIA UNIVERSIDADE CATÓLICA DO RIO DE JANEIRO

RUA MARQUÊS DE SÃO VICENTE, 225 - CEP 22453-900

RIO DE JANEIRO - BRASIL 


\title{
Ofícios de Alerta na Comissão de Valores Mobiliários
}

\author{
por \\ Paula Leonette Rangel
}

Monografia apresentada ao Departamento de Direito da Pontificia Universidade Católica do Rio de Janeiro (PUC-Rio) para a obtenção do Título de Bacharel em Direito.

Orientadora: Norma Jonssen Parente

2015.1 
À minha mãe,

Graça, por dar sentido a tudo. 


\section{Agradecimentos}

Gostaria de agradecer à minha família. Graça, Gustavo e Priscila, por formarem, em cada vírgula, o que eu sou, com todo o amor que há nesse mundo.

À Denise, Mani e Jorge, minha segunda família, inundando minhas lacunas com tanto encanto.

Ao Bartô, que, na ausência de palavras, só me resta sentir.

À minha querida orientadora, Norma. Das experiências, que se tornaram objetivos. Dos ensinamentos, que se tornaram escadas.

E ao meu Mauricio. Sempre. 


\section{Resumo}

No presente trabalho, trataremos sobre o Ofício de Alerta, emitido pela Comissão de Valores Mobiliários, com base no Sistema de Supervisão Baseado em Risco.

O instrumento, inspirado na Securities and Exchange Commission, é uma medida educativa ao mercado e uma forma de evitar a instauração de Processo Administrativo Sancionador. Os Ofícios de Alerta são enviados quando as companhias executam atos que são considerados de risco ou de menor potencial ofensivo pela Comissão de Valores Mobiliários. Ou seja, os Ofícios de Alerta são enviados quando ainda não há dano ao mercado. Contudo, os Ofícios de Alerta vêm sendo emitidos às companhias mesmo quando praticam ilícitos concretos.

Além disso, Comissão de Valores Mobiliários não vem publicando esses Ofícios.

Assim, com base em caso concreto, o objetivo deste trabalho é demonstrar as razões de emissão dos Ofícios de Alerta e a necessidade de sua ampla divulgação. Para que o mercado possa se beneficiar das diretrizes apontadas pela Comissão de Valores mobiliários, é essencial que se cumpra o princípio da publicidade a que está sujeito a autarquia, nos termos do Art. 37, da Constituição Federal.

\section{Palavras-Chave}

Comissão de Valores Mobiliários - Ofícios - Ofício de Alerta - Processo Administrativo Sancionador - Princípio da Publicidade - Mercado de Capitais 


\section{Sumário}

1. Introdução ........................................................................................................................ 9

2. A Securities and Exchange Commission ("SEC")........................................... 11

2.1. O que é .................................................................................................................... 11

2.2. Formas de controle ....................................................................................... 12

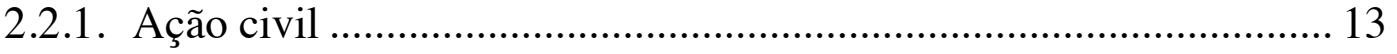

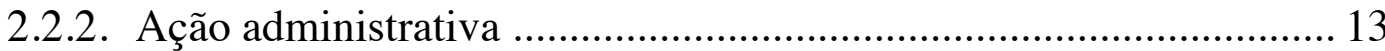

2.3. Economia aos meios processuais: Deficiency Letter .............................. 14

3. A Comissão de Valores Mobiliários (“CVM”) .............................................. 15

3.1. O que é .......................................................................................................... 15

3.2. Formas de controle .................................................................................... 16

3.3. Economia aos meios processuais: Ofícios de Alerta.............................. 17

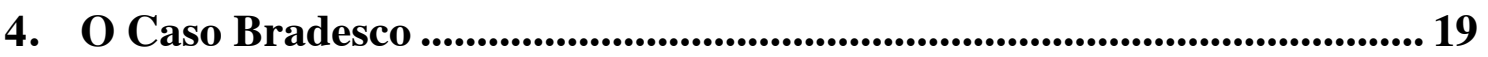

4.1. Interpelação da Superintendência de Relações com Empresas e pedido de interrupção de prazo de convocação de assembleia..................... 19

4.1.1. Interpelação da Superintendência de Relações com Empresas ........ 19

4.1.2. O pedido de interrupção de prazo de convocação de assembleia pela

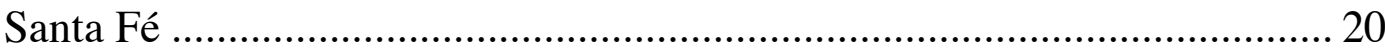

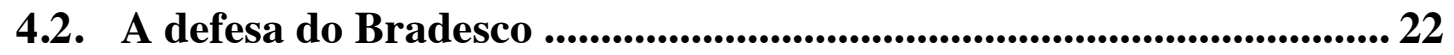

4.3. Relatório de análise da SEP e apreciação do Colegiado ...................... 24

5. Conversão do procedimento investigativo em Ofício de Alerta ............... 27

5.1. Investigação da SEP e a emissão do Ofício de Alerta .......................... 27

5.2. Recurso da Santa Fé e a decisão do Colegiado ....................................... 29

6. Ofício de Alerta x Processo Administrativo Sancionador ........................... 32

6.1. Processo Administrativo Sancionador .................................................... 32

6.2. Ofícios de Alerta ............................................................................................... 33

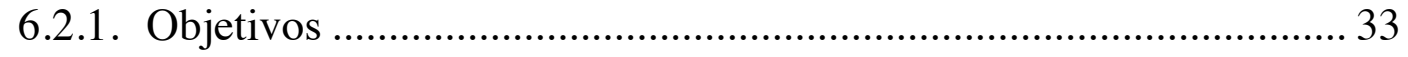

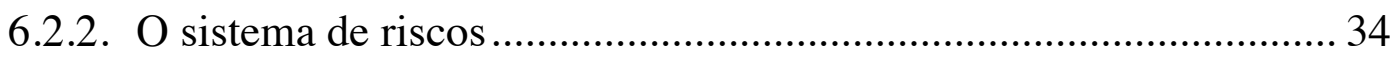

6.2.3. Classificação das ameaças............................................................... 35 
6.2.4. Ofícios de Alerta no caso concreto 36

7. A Problemática da falta de publicidade do Ofício de Alerta .................. 39

8. Conclusão .................................................................................................... 42

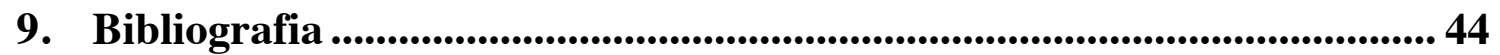




\section{Abreviações}

\begin{tabular}{|l|l|}
\hline Bradesco & Banco Bradesco S.A. \\
\hline CVM & Comissão de Valores Mobiliários \\
\hline Deliberação n ${ }^{\circ} 542$ & Deliberação CVM n ${ }^{\circ} 542$ \\
\hline Departamento de Inspeção & $\begin{array}{l}\text { Departamento de Inspeção e Análise de } \\
\text { Ética }\end{array}$ \\
\hline Plano & Plano Bienal 2015-2016 \\
\hline Santa Fé & $\begin{array}{l}\text { Santa Fé Aquarius Fundo de } \\
\text { Investimento Multimercado }\end{array}$ \\
\hline SBR & $\begin{array}{l}\text { Sistema de Supervisão Baseada em } \\
\text { Risco }\end{array}$ \\
\hline SEC & Securities And Exchange Commission \\
\hline SEP & $\begin{array}{l}\text { Superintendência de Relações com } \\
\text { Empresas }\end{array}$ \\
\hline SPS & $\begin{array}{l}\text { Superintendência de Processos } \\
\text { Sancionadores }\end{array}$ \\
\hline & \\
\hline
\end{tabular}




\section{Introdução}

O Processo Administrativo Sancionador é importante instrumento regulatório da Comissão de Valores Mobiliários. Quando esses processos sancionadores são exagerados para o ato cometido, cabe à autarquia a elaboração de um método alternativo.

Assim, criou-se os Ofícios de Alerta. Por meio desses Ofícios, o órgão regulador alerta as companhias sobre os riscos que determinada conduta representa ao mercado, sem, desse modo, aplicar nenhuma sanção administrativa às companhias. Em caso de repetição, cabe à Comissão de Valores Mobiliários a instauração do procedimento sancionador, buscando a correção dos danos causados ao mercado de valores mobiliários.

Por sua natureza de correção, é importante que os acionistas das companhias alertadas tenham acesso a eles. O mercado só se beneficiará das diretrizes da Comissão de Valores Mobiliários se o princípio constitucional da publicidade for observado. Contudo, não há previsão da obrigatoriedade da Comissão de Valores Mobiliários dar publicidade aos Ofícios de Alerta, em nosso Direito.

A proposta do presente trabalho, portanto, é analisar o instrumento do Ofício de Alerta e a necessidade de alteração regulatória sobre a sua publicidade.

Com base no caso concreto descrito nos Processos Administrativos CVM $\mathrm{n}^{\circ} \mathrm{RJ} 2010 / 17202$ e RJ2010/16884, estudaremos o propósito do referido mecanismo, e os reflexos de sua falta de publicidade.

Desse modo, nos Capítulos 2 e 3, mostraremos, simplificadamente, (2.1 e 3.1) o que são a Securities and Exchange Commission e a Comissão de Valores Mobiliários, (1.2 e 2.2) seus principais instrumentos regulatórios e (2.3 e 3.3) seus meios econômicos para não se chegar à instauração de processo: a Deficiency Letter e os Ofícios de Alerta, respectivamente. 
Nos Capítulos 4 e 5, exporemos os fatos dos Processos Administrativos CVM n ${ }^{\circ}$ RJ2010/17202 e RJ2010/16884, do Banco Bradesco, com o passo-apasso do processo.

Nos Capítulos 6 e 7, respectivamente, estudaremos a distinção teleológica entre os Processos Administrativos Sancionadores e os Ofícios de Alerta, e a problemática da falta de publicidade destes. No Capítulo 6, estudaremos os motivos que levam às superintendências da Comissão de Valores Mobiliários a preferirem o envio de Ofício de Alerta à instauração de Processo Administrativo Sancionador. No Capítulo 7, estudaremos a falta de publicidade dos Ofícios de Alerta.

Por fim, faremos breve conclusão da monografia, destacando os principais aspectos abordados ao longo do texto.

Como metodologia do trabalho, utilizamos, basicamente, a análise da literatura jurídica brasileira, das informações disponibilizadas pela Securities and Exchange Commission aos integrantes do mercado, decisões administrativas da própria Comissão de Valores Mobiliários, bem como análise de dispositivos da Constituição da República Federativa do Brasil e das Leis 6.385 e 6.404, ambas de 1976. 


\section{A Securities and Exchange Commission ("SEC")}

\subsection{0 que é}

Com a Grande Depressão, em 1929, houve grande perda de confiança no mercado de capitais. Pequenos e grandes investidores perderam dinheiro em grandes proporções, o que desmotivou o mercado. A retomada da confiança era essencial para que a economia fosse restaurada. Dessa forma, o Congresso americano tratou de realizar audiências para que fossem identificados os problemas e apontadas as soluções.

Decorrente das audiências e de estudos delas oriundos, foi promulgada a Securities Act of 1933. Essa lei, conjuntamente com a Securities Exchange Act of $1934^{1}$, responsável pela criação da SEC, objetivou restaurar a confiança no mercado de capitais, ao promover a divulgação de informações mais confiáveis e regras mais claras aos investidores e ao mercado ${ }^{2}$.

Dessa forma, pode-se dizer que o objetivo da SEC é proteger os investidores, mantendo o mercado justo, ordenado e eficiente, e facilitando a formação de capital.

Nos Estados Unidos, as leis e normas que regulam o mercado de valores mobiliários derivam de um simples conceito: todos os investidores, sejam grandes instituições financeiras ou investidores particulares, devem ter acesso a informações básicas sobre o investimento, antes de fazê-lo e enquanto o possuir.

Para que esse objetivo seja cumprido, a SEC exige que as companhias disponibilizem informações ao público, financeiras ou não, promovendo uniformização do acesso à informação a todos os investidores, de modo a ser-

\footnotetext{
1 "The Act empowers the SEC with broad authority over all aspects of the securities industry. This includes the power to register, regulate, and oversee brokerage firms, transfer agents, and clearing agencies as well as the nation's securities self regulatory organizations (SROs)" disponível em $<$ http://www.sec.gov/about/whatwedo.shtml\#laws>. Acesso em 28 de junho de 2014.

${ }^{2}$ Disponível em <http://www.sec.gov/about/whatwedo.shtml\#.U4StjJRdVgw>. Acesso em 28 de junho de 2014.
} 
lhes útil na tomada de decisão quanto à compra, venda ou manutenção de um valor mobiliário em particular.

Para que isso seja possível, é essencial a supervisão do cumprimento legal. Todo ano, a SEC instaura centenas de processos civis, decorrentes de descumprimento da lei do mercado de capitais, contra pessoas físicas e jurídicas. São infrações típicas: insider trading, fraude contábil e provimento de informações falsas ou insuficientes, sobre certo valor mobiliário ou sobre as companhias emissoras.

\subsection{Formas de controle}

A SEC é, essencialmente, uma agência de supervisão. Para o cumprimento dessa finalidade, a Superintendência de Supervisão de Cumprimento Legal, a Division of Enforcement tem grande importância. Através dela, a SEC exerce seu papel de executora, recomendando que (i) se dê início a investigações sobre violação da lei do mercado financeiro; (ii) se instaure processo civil, em tribunal federal, ou processo administrativo, em tribunal de direito administrativo; e (iii) haja tramitação desses casos em nome da própria SEC.

As investigações da SEC são sigilosas. A SEC analisa o quanto for possível dos fatos por inquérito informal, ouvindo testemunhas, examinando os livros sociais, analisando as negociações da companhia.

Com a ordem de investigação formal, a Division of Enforcement dará início à produção de provas. Assim, intimará as testemunhas e produzirá provas de livros, registros e outros documentos relevantes.

Em seguida, a Division of Enforcement apresentará a sua análise do caso ao Colegiado da SEC. O Colegiado também analisará o caso e poderá autorizar a Division of Enforcement a entrar com um processo civil ou administrativo - essa decisão dependerá do tipo de sanção ou reforço buscado.

Além disso, o Colegiado pode negociar com os acusados, decidindo o caso sem a instauração de processo. 


\subsubsection{Ação civil}

Nas ações civis, a Division of Enforcement pode trabalhar com outras agências de supervisão. Além das agências de supervisão dos Estados Unidos, a Division of Enforcement também trabalha com agências de supervisão de outros países $^{3}$.

Para a ação civil ser instaurada, a Division of Enforcement, em nome da SEC, protocola reclamação perante a District Court, pedindo por sanção ou remédio. De amiúde, a agência requer ordem judicial, a injunction, de modo a proibir a continuidade da ação ilícita, ou a disseminação da prática de atos contra as suas regras. Essa medida pode pedir por auditorias, contabilidade para auferir fraudes, ou qualquer outro tipo de medidas especiais para supervisão.

Ademais, a SEC pode aplicar penalidades pecuniárias ou determinar que todo o lucro ilegalmente auferido seja devolvido, medida esta chamada de disgorgement. Pode, ainda, impedir que pessoa física atue como diretor ou administrador de companhia. Se achar necessário, a SEC pode incluir multas adicionais ou mandado de prisão.

\subsubsection{Ação administrativa}

A ação administrativa será julgada por um juiz de direito administrativo desvinculado da SEC. Esse juiz preside as audiências e analisa as provas apresentadas.

Ao final dessa audiência, o juiz profere uma sentença (chamada de initial decision), analisando os fatos e o mérito, e recomendando a penalidade a ser aplicada.

Tanto a Division of Enforcement, quanto o réu podem apelar da decisão à SEC, total ou parcialmente. A SEC poderá confirmar a sentença, revertê-la ou enviar o processo para audiência adicional.

\footnotetext{
${ }^{3}$ Disponível em http://www.sec.gov/about/whatwedo.shtml\#org. Acesso em 09.06.2015.
} 
As penalidades administrativas incluem ordens de cessão ou desistência do ato, suspensão ou revogação do registro de operador e de investment advisor, censura, bloqueio de sua atuação no mercado financeiro, penalidades pecuniárias e disgorgement.

\subsection{Economia aos meios processuais: Deficiency Letter}

Quando as violações à lei têm menor potencial ofensivo, a SEC pode recorrer às Deficiency Letters, de modo que o reparo dos danos causados não precise ser encaminhado à Division of Enforcement.

A Deficiency Letter é um meio rápido e informal de correção de prejuízos. Ela é emitida pelo Departamento de Inspeção e Análise de Ética ${ }^{4}{ }^{5}$ ("Departamento de Inspeção"), que é responsável pelo acompanhamento das organizações de autorregulação, de corretores, intermediários financeiros, clearing agencies, fundos de investimento e investment advisers.

O Departamento de Inspeção patrulha a observância das leis do mercado de capitais, detectando suas violações e seu desenvolvimento, passando tais informações à SEC. Um dos objetivos mais importantes de seu programa de análise é a rápida correção das pequenas violações encontradas.

Ao encontrar uma violação, o Departamento de Inspeção envia uma Deficiency Letter, apontando o problema a ser solucionado pelo participante do mercado, monitorando-o até a correção almejada.

\footnotetext{
${ }^{4}$ Chamado Office of Compliance Inspections and Examinations.

${ }^{5}$ Disponível em <http://www.sec.gov/ocie\#.U4abOZRdVgw>. Acesso em 28 de junho de 2014.
} 


\section{A Comissão de Valores Mobiliários ("CVM”)}

\subsection{O que é}

A CVM é uma agência reguladora, criada pela Lei 6.385, de 1976, muito influenciada pela estrutura da SEC. Cabe a ela o exercício das atividades elencadas no Art. $1^{\circ}$ da sua Lei, quais sejam:

“emissão, distribuição, negociação, intermediação, administração de carteiras, custódia, auditoria das companhias abertas e os serviços de consultor e analista de valores mobiliários. Ademais, também é atribuição da CVM a organização e o funcionamento das operações."

As funções da CVM são, precipuamente, de “órgão regulador $e$ fiscalizador do mercado de valores mobiliários"7.

Sua função reguladora dá a ela o "poder de regular as matérias expressamente previstas na Lei das Sociedades Anônimas [Lei $n^{\circ}$ 6.404/76] e na própria Lei $n^{\circ}$ 6.385/1976 (artigo $8^{\circ}$, I)"»8.

Por meio da sua função fiscalizadora, a CVM impede que ocorram ilícitos no mercado, resguardando o interesse dos investidores, coibindo e punindo condutas danosas. "Dessa forma, a CVM age imbuída de seu poder de polícia, ou seja, limitando a liberdade individual em prol de um interesse público ou coletivo" .

Em outras palavras,

“A função fiscalizadora objetiva coibir abusos, fraudes e práticas não equitativas, bem como promover um fluxo permanente e correto de informações aos investidores. No exercício dessas funções, poderá a CVM realizar inquéritos, punir administradores, acionistas controladores e intermediários do mercado que tenham agido de forma incorreta." ${ }^{10}$ (grifos do autor)

\footnotetext{
${ }^{6}$ Eizirik, Nelson; Gaal, Ariádna B.; Parente, Flávia; Henriques, Marcus de Freitas. Mercado de capitais regime jurídico. 3 ed. rev. e ampl. Rio de Janeiro: Renovar, 2011. p. 259.

7 Ibid. p. 259.

${ }^{8}$ Ibid. p. 264.

${ }^{9}$ Ibid. p. 276.

${ }^{10}$ Borba, José Edwaldo Tavares. Direito societário - 13. ed. rev. e atual. - Rio de Janeiro: Renovar, 2012, p. 185-186.
} 
Além das funções de regulação e fiscalização, Tavares Borba assinala a existência de funções registrária, consultiva e de fomento ${ }^{11}$.

A função registrária ocorre no registro de empresas, no registro de emissão e no registro de intermediários, isto é, para a empresa ter o registro de companhia aberta e poder negociar suas ações em bolsa e/ou em mercado de balcão, e para emitir novos valores mobiliários.

A função consultiva seria posta em prática através de pareceres de orientação, conforme enuncia o Art. 13, da Lei 6.385:

Artigo 13, da Lei 6.385, de 1976 - "A Comissão de Valores Mobiliários manterá serviço para exercer atividade consultiva ou de orientação junto aos agentes do mercado de valores mobiliários ou a qualquer investidor."

Por fim, com a função de fomento, cabe à CVM o estímulo e a promoção do desenvolvimento do mercado de valores mobiliários.

\subsection{Formas de controle}

A CVM poderá instaurar Processo Administrativo Sancionador para pôr em prática a sua função fiscalizadora e seu poder de polícia. Esse procedimento será iniciado em casos de violação da lei societária, por atos ilegais, práticas não equitativas de administradores, membros do Conselho Fiscal e acionistas da companhia aberta, dos intermediários e demais participantes do mercado ${ }^{12}$. Quando houver comprovação da infração, caberá a CVM a aplicação das penalidades previstas no art. 11 , da Lei $6.385 / 76^{13}$, sem prejuízo de responsabilização civil ou penal ${ }^{14}$.

\footnotetext{
${ }^{11}$ Ibid. p. 185 .

${ }^{12}$ Art. $9^{\circ}$, inciso V - "apurar, mediante processo administrativo, atos ilegais e práticas não eqüitativas de administradores, membros do conselho fiscal e acionistas de companhias abertas, dos intermediários e dos demais participantes do mercado".

${ }^{13}$ Art. 11 - "A Comissão de Valores Mobiliários poderá impor aos infratores das normas desta Lei, da lei de sociedades por ações, das suas resoluções, bem como de outras normas legais cujo cumprimento lhe incumba fiscalizar, as seguintes penalidades:

I - advertência;

II - multa;
} 


\title{
3.3. Economia aos meios processuais: Ofícios de Alerta
}

\author{
Em 2006, foi implementado o Sistema de Supervisão Baseada em Risco
} (“SBR”) na CVM, pela Resolução CMN no 3.427. Conforme o Art. $1^{\circ}$, da Resolução ${ }^{\circ} 3.427$, o SBR seria o modelo contemplado para se concretizar a

"política a ser adotada na organização e na supervisão do funcionamento do mercado de valores mobiliários pela Comissão de Valores Mobiliários (CVM), bem como na orientação geral de suas atividades finalísticas."

Esse modelo (I) identifica os riscos a que o mercado de valores mobiliários está exposto; (II) dimensiona os referidos riscos, classificando-os segundo níveis de dano potencial; (III) estabelece formas de mitigar os riscos identificados e dimensionados; e (IV) controla e monitora a ocorrência dos riscos ${ }^{15}$.

$\mathrm{Na}$ forma do Art. $2^{\circ}$ da Resolução $\mathrm{n}^{\circ}$ 3.427, caberia à CVM a implementação de um SBR,

"adotando mecanismos institucionais de organização de suas atividades e de priorização de suas ações de regulação e fiscalização, capazes de permitir a identificação, o dimensionamento, a mitigação, o controle e o monitoramento dos riscos que possam afetar a implementação de seus mandatos legais."

Para concretizar a política de supervisão do SBR e considerando que Processos Administrativos Sancionadores precisam de justa causa ${ }^{16}$, de danos concretos ao mercado para serem instaurados, a CVM editou a Deliberação CVM

\footnotetext{
III - suspensão do exercício do cargo de administrador ou de conselheiro fiscal de companhia aberta, de entidade do sistema de distribuição ou de outras entidades que dependam de autorização ou registro na Comissão de Valores Mobiliários;

IV - inabilitação temporária, até o máximo de vinte anos, para o exercício dos cargos referidos no inciso anterior;

$V$ - suspensão da autorização ou registro para o exercício das atividades de que trata esta Lei; $V I$ - cassação de autorização ou registro, para o exercício das atividades de que trata esta Lei; VII - proibição temporária, até o máximo de vinte anos, de praticar determinadas atividades ou operações, para os integrantes do sistema de distribuição ou de outras entidades que dependam de autorização ou registro na Comissão de Valores Mobiliários;

VIII - proibição temporária, até o máximo de dez anos, de atuar, direta ou indiretamente, em uma ou mais modalidades de operação no mercado de valores mobiliários".

${ }^{14}$ Art. $9^{\circ}$, inciso VI - "aplicar aos autores das infrações indicadas no inciso anterior as penalidades previstas no Art. 11, sem prejuízo da responsabilidade civil ou penal".

${ }^{15}$ Em conformidade com o art. $1^{\circ}$, parágrafo único, da Resolução CMN n ${ }^{\circ} 3.427$, de 2006.

${ }^{16}$ Item (ii), da Deliberação CVM no 542, de 2008.
} 
$n^{\circ} 542$, de 2008 (“Deliberação n ${ }^{\circ} 542$ ”), que previa a criação dos Ofícios de Alerta.

Os Ofícios de Alerta seriam uma forma da CVM priorizar "suas ações de regulação e fiscalização para controle e monitoramento dos riscos que possam afetar a implementação de seus mandatos legais" ${ }^{17}$.

Esses Ofícios são, portanto, uma forma de pôr em prática os princípios constitucionais da eficiência e economicidade.

Os Ofícios de Alerta podem exigir a correção dos prejuízos causados, caso a CVM entenda que essa medida se aplica ao caso concreto. Contudo, diferentemente do que acontece na SEC com as Deficiency Letters, a CVM não monitora a correção daqueles prejuízos.

${ }^{17}$ Item (i), da Deliberação CVM n ${ }^{\circ}$ 542, de 2008. 


\section{O Caso Bradesco}

O Banco Bradesco S.A., em 22.11.2010, publicou fato relevante anunciando o aumento de seu capital social, que seria discutido em sua assembleia geral extraordinária. Para o aumento de capital, a sua administração estipulou preço único de emissão tanto para as ações ordinárias, quanto para as ações preferenciais, no valor de $\mathrm{R} \$ 24,06$.

\subsection{Interpelação da Superintendência de Relações com Empresas e pedido de interrupção de prazo de convocação de assembleia}

\subsubsection{Interpelação da Superintendência de Relações com Empresas}

A Superintendência de Relações com Empresas da CVM - SEP, no exercício de seu poder fiscalizador, iniciou o Processo Administrativo CVM n ${ }^{\circ}$ RJ2010/16884, em 17.12.2013, após o Bradesco publicar o fato relevante de 22.11.2010.

Diante disso, a SEP encaminhou o $1^{\circ}$ ofício à Companhia ${ }^{18}$, solicitando sua manifestação. O referido ofício observou que os acionistas de ações preferenciais seriam beneficiados, por conta da liquidez e das cotações díspares de ambas as espécies de ação.

Em resposta, o Bradesco alegou que (i) a fixação de um preço de emissão único seria a regra geral; (ii) a fixação de preços diferenciados, além de exceção, constituiria procedimento sem obrigatoriedade; (iii) no presente caso, não estariam presentes os requisitos para a adoção do preço diferenciado; (iv) as ações ordinárias da Companhia não integrariam índice de representativa negociabilidade, não fazendo parte nem do Ibovespa, nem do IBrX-50; (v) o

\footnotetext{
${ }^{18}$ OFÍCIO/CVM/SEP/GEA-3/No1119/10, de 29 de novembro de 2010.
} 
critério a ser adotado na assembleia geral extraordinária seria o mesmo adotado em aumentos de capital passados ${ }^{19}$; e (vi) o preço estabelecido, com base no art. 170, Parágrafo $1^{\circ}$, inciso III, da Lei $6.404 / 76^{20}$, seria inferior ao valor de cotação de ambas as espécies de ações, evitando a diluição injustificada de acionistas de determinada espécie de ações da Companhia.

No dia 07.12.2010, a SEP encaminhou o $2^{\circ}$ ofício ao Bradesco ${ }^{21}$. Nele, a CVM apontou que o conceito de liquidez do Art. 170, Parágrafo $1^{\circ}$, inciso III não se aplica ao caso concreto. Assim, mostrou que não é razoável a fixação de um preço único para ambas as espécies, considerando que as cotações das espécies de ações são notoriamente díspares e ambas possuem significativa liquidez. A superintendência ainda alertou que a manutenção do preço único importaria em tratamento não equitativo entre os acionistas de espécies distintas de ações, conforme o exposto no Parecer de Orientação CVM n ${ }^{\circ}$ 05, de 1979.

\subsubsection{O pedido de interrupção de prazo de convocação de assembleia pela Santa Fé}

Paralelamente aos questionamentos da SEP, foi instaurado o Processo Administrativo CVM no RJ2010/17202, a partir do pedido de interrupção de prazo de antecedência da convocação da assembleia, com base no Art. 124, Parágrafo $5^{\circ}$, inciso II, da Lei 6.404, feito pela Santa Fé Aquarius Fundo de Investimentos Multimercado ("Pedido de Interrupção"). O Pedido de Interrupção foi feito em função do critério de fixação do preço de emissão das ações proposto para a assembleia.

\footnotetext{
${ }^{19}$ Ocorridos nas assembleias gerais extraordinárias datadas de 09.12.2004, 05.10.2006 e 01.01.2008.

${ }^{20}$ Art. 170 - "Depois de realizados 3/4 (três quartos), no mínimo, do capital social, a companhia pode aumentá-lo mediante subscrição pública ou particular de ações.

$\$ 1^{\circ}$ O preço de emissão deverá ser fixado, sem diluição injustificada da participação dos antigos acionistas, ainda que tenham direito de preferência para subscrevê-las, tendo em vista, alternativa ou conjuntamente:

(...)

III - a cotação de suas ações em Bolsa de Valores ou no mercado de balcão organizado, admitido ágio ou deságio em função das condições do mercado."

${ }^{21}$ OFÍCIO/CVM/SEP/GEA-3/N¹172/10, de 07 de dezembro de 2010.
} 
Pelo Pedido de Interrupção foi questionada a falta de justificativa do critério adotado para a fixação de preço único tanto para as ações ordinárias quanto para as preferenciais. Como as ações ordinárias tinham cotação inferior à das ações preferenciais, a Santa Fé mostrou que não seria razoável fixar o mesmo preço a ambas as espécies. Segundo o Parecer de Orientação CVM n ${ }^{\circ} 05$, essa situação resultaria em "um ilógico e elevado custo de capital, pois se estariam colocando estas ações, injustificadamente, a um preço (...) inferior ao seu valor de cotação" 22 .

Além disso, no Pedido de Interrupção foi relatado que o Banco não teria pormenorizado os aspectos econômicos que fundamentaram a fixação do preço, nem discriminado os critérios adotados para a determinação do valor adotado. A proposta do conselho de administração do Bradesco teria se limitado a indicar a fixação segundo os dizeres do Art. 170, Parágrafo $1^{\circ}$, da Lei $6.404^{23}$, sem especificar o inciso utilizado.

Segundo a Santa Fé, este cenário desrespeitaria o direito à informação adequada dos investidores. Não haveria amplo acesso às informações necessárias à tomada de decisão pelos acionistas, que também não teriam capacidade de decidir se os valores estipulados seriam adequados. Pelo Pedido de Interrupção entendeu-se que esse cenário resultaria na infração ao Art. 170, Parágrafo $7^{\circ}$, da Lei 6.404:

Art. 170 - "Depois de realizados 3/4 (três quartos), no mínimo, do capital social, a companhia pode aumentá-lo mediante subscrição pública ou particular de ações.

(...)

$\S 7^{\circ}$ A proposta de aumento do capital deverá esclarecer qual o critério adotado, nos termos do $\S 1^{\circ}$ deste artigo, justificando pormenorizadamente os aspectos econômicos que determinaram a sua escolha."

\footnotetext{
${ }^{22}$ Parecer de Orientação CVM n ${ }^{\circ}$ 05, de 1979, fl. 03.

${ }^{23}$ Art. 170 - "Depois de realizados 3/4 (três quartos), no mínimo, do capital social, a companhia pode aumentá-lo mediante subscrição pública ou particular de ações.

$\S 1^{\circ} O$ preço de emissão deverá ser fixado, sem diluição injustificada da participação dos antigos acionistas, ainda que tenham direito de preferência para subscrevê-las, tendo em vista, alternativa ou conjuntamente:

I - a perspectiva de rentabilidade da companhia;

II - o valor do patrimônio líquido da ação;

III - a cotação de suas ações em Bolsa de Valores ou no mercado de balcão organizado, admitido ágio ou deságio em função das condições do mercado.

(...)"
} 
A Santa Fé ainda entendeu que a permissão do Art. 170, Parágrafo $1^{\circ}$, da Lei 6.404, não inclui deduções do preço que tenham como objetivo viabilizar a cessão do direito de preferência. Com a fixação do preço de emissão, a Companhia possibilitou que os frutos da operação fossem desviados para premiar determinado grupo de acionistas, o que não estaria previsto ou lastreado na lei.

Esse prêmio proporcionaria uma diluição injustificada dos antigos acionistas, o que representaria o abuso de poder de controle, conforme o Art. 177, Parágrafo $1^{\circ}$, alínea “c”, da Lei $6.404^{24}$.

“A possibilidade de ceder o direito de preferência, portanto, não elimina a obrigatoriedade de o preço de emissão ser estabelecido de acordo com o valor econômico. A lei não instituiu tal exceção. A única possibilidade de não ser adotado o valor decorre de diluição justificada. A companhia não pode dar um desconto no preço de emissão pelo valor econômico para permitir que o acionista obtenha um ganho pessoal com a cessão onerosa do direito de preferência." 25

Por fim, pelo Pedido de Interrupção entendeu-se que a diluição injustificada teria sido causada pelo deságio estipulado. Para a Santa Fé, o uso de um deságio de $10 \%$ a $25 \%$ no preço de emissão de ações das empresas cotadas na bolsa seria o usual. Contudo, no presente caso, o deságio nas ações preferenciais do Bradesco teria sido de $28,65 \%$.

\subsection{A defesa do Bradesco}

O Bradesco protocolou sua defesa, em 09.12.2010, reiterando que a fixação de preço único teria sido realizada de forma lícita e conforme critérios da lei.

\footnotetext{
${ }^{24}$ Art. 117 - "O acionista controlador responde pelos danos causados por atos praticados com abuso de poder.

$\S 1^{\circ}$ São modalidades de exercício abusivo de poder:

(...)

c) promover alteração estatutária, emissão de valores mobiliários ou adoção de políticas ou decisões que não tenham por fim o interesse da companhia e visem a causar prejuizo a acionistas minoritários, aos que trabalham na empresa ou aos investidores em valores mobiliários emitidos pela companhia;

$(\ldots)$ ")

${ }^{25}$ Processo Administrativo CVM n ${ }^{\circ}$ RJ2010/17202, fl. 27.
} 
Quanto ao critério utilizado, a Companhia teria adotado o critério de cotação das ações de emissão do Bradesco na BM\&FBovespa. Para esse método, teria utilizado o valor médio ponderado das cotações das ações ordinárias e preferenciais, em determinado período de tempo, adicionando, à essa média, um deságio de $20 \%$. Esse deságio teria sido necessário para permitir que o aumento do capital fosse realizado com subscrição de $100 \%$ das ações emitidas.

Quanto à fixação de preço único, o Bradesco reiterou que essa seria a regra geral em procedimentos de aumento de capital. Segundo o Banco, essa regra não geraria nenhuma forma de prejuízo aos detentores de determinada espécie de ações.

Além disso, o sistema adotado de fixação de preço não teria o objetivo de beneficiar os acionistas detentores de ações preferenciais, ou viabilizar a cessão de direito de preferência.

Por fim, o Bradesco apresentou a impossibilidade de se alterar data de realização da assembleia geral extraordinária e a importância de realizá-la na data prevista. Esta impossibilidade resultaria da improcedência das alegações da Santa Fé, baseadas no Art. 124, Parágrafo 5 ${ }^{\circ}$, inciso II, da Lei $6.404^{26}$. Tal artigo traria prerrogativa excepcional, que só seria aplicada quando verificada, a priori e independentemente de dilação probatória, a existência de flagrantes ilegalidades nas deliberações. Além disso, qualquer suspensão de uma assembleia geral extraordinária geraria prejuízos, especialmente em se tendo um aumento de capital como ordem do dia.

\footnotetext{
26 Art. 124 - “A convocação far-se-á mediante anúncio publicado por 3 (três) vezes, no mínimo, contendo, além do local, data e hora da assembléia, a ordem do dia, e, no caso de reforma do estatuto, a indicação da matéria.

(...)

$\S 5^{\circ}$ A Comissão de Valores Mobiliários poderá, a seu exclusivo critério, mediante decisão fundamentada de seu Colegiado, a pedido de qualquer acionista, e ouvida a companhia:

(...)

II - interromper, por até 15 (quinze) dias, o curso do prazo de antecedência da convocação de assembléia-geral extraordinária de companhia aberta, a fim de conhecer e analisar as propostas a serem submetidas à assembléia e, se for o caso, informar à companhia, até o término da interrupção, as razões pelas quais entende que a deliberação proposta à assembléia viola dispositivos legais ou regulamentares."
} 


\subsection{Relatório de análise da SEP e apreciação do Colegiado}

Em seu relatório ${ }^{27}$, a SEP entendeu, com base na proposta do Conselho de Administração, que o Bradesco teria utilizado o critério de cotação para a fixação do preço das ações.

Quanto à utilização de deságio da ordem de $28,65 \%$, no preço das ações preferenciais, a SEP entendeu que, "para fixar o preço de emissão, o referido deságio se mostra fundamental para a consecução da operação, uma vez que, de outro modo, o preço de emissão não se revelaria atrativo para os acionistas ordinaristas (...)."28

Quanto à fixação de preço único, a SEP deu razão à Santa Fé, para a fixação de preços distintos para as ações preferenciais e ordinárias. Da forma como foi proposta, a operação geraria vantagem aos acionistas preferencialistas, que teriam direito de subscrever ações mais valorizadas no mercado - as ações preferenciais - por um preço inferior.

A SEP compreendeu que a manutenção dessa situação geraria um tratamento não equitativo entre os acionistas, com vantagens que o legislador não teria tratado como compensatórias à ausência de direito de voto ${ }^{29}$.

\footnotetext{
${ }^{27} \mathrm{RA} / \mathrm{CVM} / \mathrm{SEP} / \mathrm{GEA}-3 / \mathrm{n}^{\circ} 119 / 10$, de 14 de dezembro de 2010.

${ }^{28}$ Processo Administrativo CVM n ${ }^{\circ}$ RJ2010/17202, fl. 169.

${ }^{29}$ Art. 17, Parágrafo $1^{\circ}$, da Lei 6.404 - “As preferências ou vantagens das ações preferenciais podem consistir:

I - em prioridade na distribuição de dividendo, fixo ou mínimo;

II - em prioridade no reembolso do capital, com prêmio ou sem ele; ou

III - na acumulação das preferências e vantagens de que tratam os incisos I e II.

$\S 1$ Independentemente do direito de receber ou não o valor de reembolso do capital com prêmio ou sem ele, as ações preferenciais sem direito de voto ou com restrição ao exercício deste direito, somente serão admitidas à negociação no mercado de valores mobiliários se a elas for atribuída pelo menos uma das seguintes preferências ou vantagens:

I - direito de participar do dividendo a ser distribuído, correspondente a, pelo menos, $25 \%$ (vinte e cinco por cento) do lucro líquido do exercício, calculado na forma do art. 202, de acordo com o seguinte critério:

a) prioridade no recebimento dos dividendos mencionados neste inciso correspondente a, no mínimo, 3\% (três por cento) do valor do patrimônio líquido da ação; $e$

b) direito de participar dos lucros distribuídos em igualdade de condições com as ordinárias, depois de a estas assegurado dividendo igual ao mínimo prioritário estabelecido em conformidade com a alínea a; ou

II - direito ao recebimento de dividendo, por ação preferencial, pelo menos $10 \%$ (dez por cento) maior do que o atribuído a cada ação ordinária; ou

III - direito de serem incluídas na oferta pública de alienação de controle, nas condições previstas no art. 254-A, assegurado o dividendo pelo menos igual ao das ações ordinárias.
} 
Desse modo, a área técnica concluiu que, embora o Parecer de Orientação

CVM no 05 determine a fixação de preço único como regra, sua aplicação geraria tratamento não equitativo,

"uma vez que não se pode atribuir vantagem a determinado grupo de acionistas sem a presença de elementos excepcionais que justifique tal procedimento, e o pressuposto básico do tratamento equitativo entre os acionistas deve ser resguardado." 30

Assim, concluiu a SEP

"42. Pelo exposto, a meu ver, considerando que a atribuição do preço único representaria uma vantagem indevida aos acionistas preferencialistas em relação aos ordinaristas, a não fixação de preços distintos entre as espécies de ações de emissão é irregular.

43. Convém destacar que não há nenhum dispositivo expresso na Leu ${ }^{\circ}$ 6.404/76 que determina a fixação de preços distintos em casos como o presente, no entanto, a fixação do preço único viola o pressuposto básico do direito societário, que consiste no tratamento equitativo entre os acionistas, além de extrapolar o disposto no art. 17 da LSA, que lista as vantagens passivas de atribuição às ações preferenciais, em decorrência da supressão do direito de voto.

$(\ldots)$

45. Não obstante, a meu juízo, o pedido de interrupção resta prejudicado, uma vez que o entendimento acerca da irregularidade da proposta já está assentado, sendo desnecessário o prazo previsto neste dispositivo para manifestar tal conclusão, o que inclusive já foi comunicado à companhia, por meio do OFÍCIO/CVM/SEP/GEA3/No1172/10, de 07.12.10." ${ }^{31}$

Por isso, a SEP não acatou o pedido de interrupção do curso do prazo de antecedência da convocação da assembleia geral extraordinária do Bradesco. Sugeriu, ainda, que fosse alertado ao Banco que haveria apuração das responsabilidades em procedimento sancionador caso fosse levado adiante a proposta de aumento de capital nos moldes propostos, isto é, com fixação de preço único de emissão.

Finalmente, o Colegiado da CVM, em 14.12.2010, indeferiu o pedido de interrupção formulado pela Santa Fé, vez

"que a formação de convicção suficiente sobre a ilegalidade da proposta dependeria de apuração que, neste caso, se considerou impossível dentro do exíguo prazo de 15 dias

\footnotetext{
$(\ldots)$

${ }^{30}$ Processo Administrativo CVM n ${ }^{\circ} \mathrm{RJ} 2010 / 17202$, fl. 171.

${ }^{31}$ Processo Administrativo CVM n ${ }^{\circ}$ RJ2010/17202, fl. 172.
} 
estabelecido no inciso II do $\$ 5^{\circ}$ do art. 124, da LSA, devendo, ao reverso, tal apuração ser realizada mediante procedimento investigativo próprio."

${ }^{32}$ Processo Administrativo CVM n ${ }^{\circ}$ RJ2010/17202, fl. 175. 


\section{Conversão do procedimento investigativo em Ofício de Alerta}

\subsection{Investigação da SEP e a emissão do Ofício de Alerta}

Após a decisão do Colegiado, a SEP deu seguimento ao procedimento investigativo das irregularidades relacionadas ao aumento de capital ${ }^{33}{ }^{34}$, no âmbito do Processo Administrativo CVM n ${ }^{\circ}$ RJ2010/16884.

Em sua análise, a SEP verificou ter ocorrido irregularidades no aumento de capital quanto ao disposto no Art. 170, da Lei 6.404.

A área técnica entendeu que a fixação de preço único violou o Art. 170, Parágrafo $1^{\circ}$, da Lei 6.404, diluindo injustificadamente os acionistas.

Em suas considerações sobre o Art. 170, a SEP abordou os seguintes pontos:

(a) o legislador criou o conceito de "valor econômico da ação" visando proteger os acionistas minoritários. Sua não observância diluiria desnecessária e injustificadamente dos acionistas que não acompanharam o aumento de capital. Em um aumento de capital, a companhia deverá analisar qual dos critérios da lei mais se aproxima do conceito de valor econômico da ação. Segundo a SEP, esse entendimento teria sido refletido no Parecer de Orientação CVM nº 01, de 1978.

(b) o Parecer de Orientação CVM n ${ }^{\circ} 01$ não permitiu interpretar os casos em que ações de mais de uma espécie ou classe são emitidas. Por isso, foi editado o Parecer de Orientação CVM no 05, que justificou a possibilidade de se adotar mais de um preço de subscrição, desde que averiguados significativos índices de negociabilidade e a existência de cotações díspares entre as espécies.

(c) tanto as ações ordinárias quanto as ações preferenciais do Bradesco são líquidas, integrantes de índices dos papéis mais negociados na Bovespa, e a

\footnotetext{
${ }^{33}$ Processo Administrativo CVM n ${ }^{\circ}$ RJ2010/16884, fl. 146.

${ }^{34} \mathrm{RA} / \mathrm{CVM} / \mathrm{SEP} / \mathrm{GEA}-3 / \mathrm{n}^{\circ} 050 / 11$.
} 
diferença entre as suas cotações representa significativa disparidade entre seus valores de mercado.

(d) o valor de emissão fixado foi abaixo do preço de mercado de ambas as espécies. O deságio verificado, em relação ao preço de mercado das ações ordinárias foi de 9,28\% e, em relação ao preço de mercado das ações preferenciais, foi de $28,65 \%$. Por isso, a SEP voltou a se manifestar no sentido de que deveriam ter sido utilizados preços diferenciados entre as espécies.

(e) a regra geral do preço único não se aplica mais. Segundo a SEP, essa regra foi emitida num contexto de mercado pouco desenvolvido. Hoje, a regra é a da utilização do preço das ações líquidas como elemento preponderante na fixação do valor das ações a serem emitidas.

(f) ofertar novas ações por preço inferior ao de mercado traria consequências: a baixa influência nas cotações, diluição desnecessária dos acionistas não-subscritores e abalo no patrimônio atual dos titulares dessas ações. A fixação do preço único só comprometeria a colocação das ações caso fosse fixado acima do valor de mercado.

(g) não haveria de se falar em ágio suplementar, já que ele representa sobrepeso da colocação das ações em relação ao seu valor nominal. O Bradesco, contudo, não possui ações com valor nominal e todos os recursos captados seriam destinados ao seu capital social.

(h) os acionistas preferenciais não seriam prejudicados pela fixação de preços distintos, posto que o preço a ser fixado seria do seu valor econômico, real. A fixação do preço das novas ações não é livre, devendo obedecer as possibilidades oferecidas pelo Art. 170, Parágrafo $1^{\circ}$, da Lei 6.404.

(i) o percentual de adesão à operação não pode ser utilizado como argumento de sua regularidade.

(j) o deságio, quanto maior for, exige que um maior número de ações seja emitido, aumentando a diluição do acionista que não participa do aumento de capital, além de aumentar os custos para a companhia. Ele representa uma diluição injustificada, não sendo entendido como valorização do direito de preferência do acionista preferencialista. 
(k) a aprovação do aumento de capital em assembleia geral extraordinária não convalidou seus vícios. Os acionistas prejudicados, isto é, os acionistas preferencialistas, não têm direito a voto em assembleia, sem poder de interferir nos termos do aumento de capital.

Ao fim de sua investigação, a superintendência entendeu que a instauração de Processo Administrativo Sancionador não era necessária. Propôs, então, o envio de Ofício de Alerta aos administradores do Bradesco. Por meio do Ofício de Alerta enviado, os administradores foram alertados que, no caso de nova inobservância do Art. 170, a SEP adotará o procedimento administrativo.

\subsection{Recurso da Santa Fé e a decisão do Colegiado}

A Santa Fé apresentou recurso à decisão da SEP, em 20.01.2012. O recurso pediu a anulação do Ofício de Alerta e a instauração de Processo Administrativo Sancionador contra os administradores do Bradesco.

A Recorrente alegou que, reconhecida a ilegalidade do aumento de capital, a superintendência deveria ter instaurado um Processo Administrativo Sancionador. Segundo a Santa Fé, não caberia à área técnica optar por não sujeitar os administradores do Banco às devidas penalidades.

A Recorrente mostrou que o envio de um Ofício de Alerta só seria adequado se o caso tratasse de irregularidades de menor potencial ofensivo, isto é, frente a violações dispositivas ou regulamentares. Este, contudo, não era o caso.

De acordo com a Santa Fé, como os atos foram danosos ao mercado de capitais e ao direito acionário de não diluição injustificada, não seria certo considerá-los meras irregularidades. Tais atos violaram normas de ordem pública e, por isso, não poderiam ser objeto de Ofício de Alerta. Ademais, a SEP, no curso do processo, já havia advertido, por diversas vezes, o Bradesco, mas sem efeito. 
Ainda, a Recorrente alegou que o Ofício de Alerta enviado não teria respeitado os dois passos exigidos pela Deliberação $n^{\circ}$ 542: (i) a exigência de correção das irregularidades cometidas e (ii) a identificação dos prejuízos a serem cobertos, o que inviabilizaria o ressarcimento dos danos sofridos pelos acionistas preferencialistas.

A Santa Fé demonstrou ainda que o Ofício de Alerta enviado não tinha sido publicado, ferindo o princípio constitucional da publicidade, desrespeitando o Art. 37, da Constituição Federal:

Art. 37 - "A administração pública direta e indireta de qualquer dos Poderes da União, dos Estados, do Distrito Federal e dos Municípios obedecerá aos princípios de legalidade, impessoalidade, moralidade, publicidade e eficiência e, também, ao seguinte: (...)"

Essa falta de publicação geraria incerteza aos acionistas da Companhia, que ficariam sem ter resposta sobre o procedimento da CVM e suas diretrizes.

Por fim, a Santa Fé apontou à violação do Dever de Diligência dos administradores do Bradesco. Além de terem prosseguido com o conclave, apesar de todas as manifestações dos acionistas e da própria CVM, os administradores do Bradesco não tomaram nenhuma medida para que o valor do deságio beneficiasse a Companhia, e não a um determinado grupo de acionistas, em detrimento do Banco.

Diante da manifestação da Santa Fé, entretanto, a SEP manteve seu entendimento anterior, no sentido de indeferir o recurso da Recorrente.

Segundo a superintendência, a Deliberação ${ }^{\circ} 542$ lhe conferiu a opção de enviar Ofícios de Alerta sem que isso violasse o Art. $9^{\circ}$, da Lei 6.385. No caso concreto, o envio foi adequado. Além disso, o Ofício de Alerta trata de irregularidades, cujo conceito, mais genérico, pode abranger as normas baixadas pela CVM e a legislação em geral.

Mesmo com o envio de diversos ofícios sobre a ilegalidade do aumento de capital proposto, a SEP entendeu que não foram suficientes para caracterizar a má-fé da administração por decidir dar prosseguimento à operação.

Quanto ao desrespeito aos passos dados dos Ofícios de Alerta dados pela Deliberação $n^{\circ} 542$, a SEP entendeu que (i) a correção das irregularidades 
cometidas só ocorrerá quando for aplicável, o que não é o caso; e (ii) quanto à identificação dos prejuízos sofridos pelos acionistas minoritários a serem cobertos, a Santa Fé não havia esclarecido quais prejuízos teriam sido sofridos.

Por fim, quanto à publicidade dos Ofícios de Alerta, a SEP entendeu que, embora esteja prescrita na Constituição Federal, em seu Art. 37, não há nenhum dispositivo que obrigue as áreas técnicas da CVM a darem ou exigirem a publicidade dos Ofícios de Alerta enviados.

O Colegiado, em 17.12.2013, acompanhou o entendimento da SEP, entendendo pelo

“22. (...) descumprimento, pela Companhia, do disposto no $\$ 1^{\circ}$ do art. 170 da lei acionária quando da fixação do preço de emissão do Aumento de Capital.

23. Ademais, (...) acredito que também o disposto no $\S 7^{\circ}$ art. 170 não foi atendido pelo Bradesco, que, para resumir, não explicou pormenorizadamente como chegou ao deságio de 9,28\% para as ações ordinárias e 28,65\% para as preferenciais." ${ }^{35}$

Mas, em relação ao procedimento adotado pela SEP, quanto à opção de envio de Ofício de Alerta, o Colegiado entendeu que não é de sua competência esse tipo de análise.

Por outro lado, apontou que, caso a análise sobre o envio do Ofício fosse de sua alçada, não teria encontrado irregularidades, pois entendeu não haver máfé da administração do Banco ao ter decidido continuar com a operação de aumento de capital.

Para o Colegiado,

“28. (...) a existência de uma infração objetiva a determinado comando legal não é suficiente para justificar, direta e automaticamente, um processo administrativo sancionador, pois o exercício de qualquer pretensão punitiva depende da cuidadosa verificação acerca da existência de justa causa."36

\footnotetext{
${ }^{35}$ Processo Administrativo CVM no RJ2010/16884, Dir. Rel. Otávio Yazbek, 17 dez. 2013.

${ }^{36}$ Processo Administrativo CVM n ${ }^{\circ}$ RJ2010/16884, Dir. Rel. Otávio Yazbek, 17 dez. 2013.
} 


\section{Ofício de Alerta x Processo Administrativo Sancionador}

O caso do Bradesco nos remete ao questionamento sobre o que levou a CVM a enviar um Ofício de Alerta ao invés de instaurar um Processo Administrativo Sancionador.

\subsection{Processo Administrativo Sancionador}

O Processo Administrativo Sancionador é o mecanismo de investigação e penalização administrativa. Por meio dele, a CVM aplica penalidades administrativas a seus regulados, em decorrência de prática de ilícitos administrativos $^{37}$, de danos ao mercado.

"O processo administrativo sancionador ou punitivo consiste na sucessão ordenada de atos por meio dos quais a Administração exerce sanções de polícia administrativa a particulares, culminando na imposição do ato administrativo sancionador." ${ }^{38}$

Sua estruturação se dá em duas etapas, sendo a primeira relacionada à investigação e a segunda relacionada ao contraditório ${ }^{39}$.

A primeira fase consiste em notificar os indiciados e em apurar a ocorrência de fatos possivelmente ilícitos e puníveis. Nessa etapa não há suposição da prática efetiva de atos ilegais.

Por não envolver certeza da prática do ilícito e de sua autoria, e para não criar presunção pública do que ainda não está confirmado, a fase inquisitória é regida pelo sigilo.

Só após investigação e provas suficientes, haverá ou não a elaboração de Termo de Acusação, pela Superintendência de Processos Sancionadores ("SPS") ou por outra Superintendência. Assim, será dado início à segunda etapa.

\footnotetext{
${ }^{37}$ Eizirik, Nelson. Reforma das S/A e do Mercado de Capitais. Renovar: Rio de Janeiro, 1997. p. 147.

${ }^{38}$ Aragão, Alexandre Santos de. Curso de direito administrativo. $2^{a}$ ed. rev. atual. e ampl. Rio de Janeiro: Forense, 2013. p. 700.

${ }^{39}$ Parecer de Orientação CVM n ${ }^{\circ}$ 06, de 28 de abril de 1980.
} 
Essa separação funcional se dá, nas palavras de Nelson Eizirik ${ }^{40}$, posto que

"É indispensável, ademais, que exista uma separação funcional entre as fases de instrução e de decisão; cada uma delas deve ser desenvolvida por um órgão distinto, de maneira a garantir a obrigatória imparcialidade da decisão proferida.

Tal orientação (...) veio a ser fortalecida (...) quando da edição do Decreto $\mathrm{n}^{\circ} 6.382$ que alterou a estrutura organizacional da CVM, criando a Superintendência de Processos Sancionadores (SPS), com a função de conduzir os Processos Administrativos Sancionadores instaurados pela Autarquia e, assim, promover a segregação das funções de fiscalização das funções acusatórias. Tal segregação tem o objetivo de trazer mais eficiência na condução dos processos administrativos sancionadores - com maior agilidade na fase de investigação e na apresentação de acusações - e de qualidade no resultado final das acusações produzidas."

Nessa segunda fase, a SPS conduzirá o processo, em conjunto com a Procuradoria Federal Especializada da CVM. Em sistema de corresponsabilidade, elaborarão o relatório de acusação.

Os acusados serão intimados, para apresentar suas defesas. Recebidas, o processo é encaminhado ao Colegiado da CVM, que deverá julgar a acusação.

"São portanto o Presidente e os demais Diretores da CVM que absolverão os imputados ou lhes aplicarão as sanções administrativas previstas na Lei 6.385/76. No Colegiado da CVM, o processo é distribuído por sorteio a um relator, a quem caberá conduzir o processo até a sessão de julgamento. Compete ao relator deferir ou indeferir pedido de provas formulado pelos acusados ou ainda determinar novas diligências que entenda cabíveis para o julgamento. Uma vez devidamente instruído, o processo é levado pelo relator a julgamento pelo Colegiado da CVM, em sessão pública, ocasião em que ainda é dada ao acusado ou a seu representante legal a possibilidade de fazer colocação oral." ${ }^{41}$

\subsection{Ofícios de Alerta}

\subsubsection{Objetivos}

Conforme exposto no item 3.3, com a implementação do SBR, a CVM passou a adotar mecanismo de identificação, controle e mitigação de riscos incorridos por seus regulados.

\footnotetext{
${ }^{40}$ Eizirik, Nelson, Gaal, Ariádna B.; Parente, Flávia; Henriques, Marcus de Freitas. Op. Cit. p. 290-291.

${ }^{41}$ Dubeux, Julio Ramalho. A Comissão de Valores Mobiliários e os principais instrumentos regulatórios do mercado de capitais brasileiro. Porto Alegre: Sergio Antonio Fabris, 2006. p. 93.
} 
Por isso, conforme a Deliberação n⿳0542, foi criado o Ofício de Alerta, com os seguintes objetivos:

“II - adotar procedimentos de prevenção e orientação aos participantes do mercado de valores mobiliários para fins de correção de eventuais irregularidades detectadas pelas Superintendências da Comissão de Valores Mobiliários;

II - as Superintendências poderão, uma vez constatada a ocorrência de irregularidade praticada no âmbito do mercado de valores mobiliários, alertar a pessoa física ou jurídica fiscalizada para o desvio observado, assinalando-lhe, se for o caso, prazo razoável para a devida correção;

III - corrigida a irregularidade apontada, a Superintendência afeta ao mérito do processo poderá, diante das circunstâncias do caso, promover o arquivamento do feito. ${ }^{, 42}$

\title{
6.2.2. O sistema de riscos
}

\begin{abstract}
"Para implementar o SBR nas atividades de acompanhamento do mercado, foram consideradas, na maioria dos casos, na classificação e na mensuração dos riscos, as características dos supervisionados, utilizando parâmetros que identificam a probabilidade de darem causa ao evento de risco e o potencial de dano ao mercado, conforme a orientação do art. $3^{\circ}, \S 2^{\circ}$ da Deliberação CVM n ${ }^{\circ} 521 / 07 . " 43$
\end{abstract}

Tratando-se de sistema de riscos, cada superintendência será responsável pelo mapeamento e classificação das ameaças, conforme o Art. $9^{\circ}$, inciso I, da Deliberação CVM n ${ }^{\circ}$ 521, de 2007:

Art. $9^{\circ}$ - "Na elaboração do Plano Bienal serão adotados os seguintes procedimentos: I - nos primeiros três meses do ano em que deva ser aprovado um Plano Bienal, o Comitê de Gestão de Risco elaborará um questionário sobre as prioridades a serem adotadas pela CVM, denominado Questionário Bienal, com base no Anexo I a esta Deliberação, que será submetido pelo Coordenador Executivo aos Superintendentes das seguintes áreas da CVM:
a) Superintendência de Relações com Empresas - SEP;
b) Superintendência de Relações com Investidores Institucionais - SIN;
c) Superintendência de Relações com o Mercado e Intermediários - SMI
d) Superintendência de Proteção e Orientação aos Investidores - SOI;
e) Superintendência de Normas Contábeis e de Auditoria - SNC;
f) Superintendência de Desenvolvimento de Mercado - SDM;
g) Superintendência de Fiscalização Externa - SFI; e
h) Superintendência de Registro de Valores Mobiliários - SRE."

\footnotetext{
42 Deliberação CVM n ${ }^{\circ}$ 542, de 2008.

${ }^{43}$ Disponível em <http://www.cvm.gov.br/menu/acesso_informacao/planos/sbr/sbr.html $\geq$. Acesso em 01 de junho de 2015 .
} 


\subsubsection{Classificação das ameaças}

A classificação das ameaças pode ser observada no Plano Bienal 20152016, aprovado pelo Colegiado da CVM, em 09.12.20144 (“Plano”). O Plano abrange as cinco grandes áreas do mercado, conforme entendimento da autarquia. Tais áreas possuem operações e agentes de mercado com parcela significativa da atividade supervisora da CVM. São elas: (i) Empresas; (ii) Fundos de Investimento; (iii) Auditores Independentes; (iv) Mercados e Intermediários; e (v) Distribuições Públicas. Vale salientar que o modelo dos Planos Bienais de SBR da CVM elenca basicamente os mesmos resultados e os mesmos riscos, desde o Plano Bienal 2009-2010.

A título exemplificativo, o Plano estabelece que a área de Empresas é supervisionada pela SEP. Em outubro de 2014, estimou-se que a referida superintendência possuía, sob a sua supervisão, 775 companhias registradas, sendo 652 companhias abertas, 13 companhias estrangeiras e 110 companhias incentivadas. ${ }^{45}$

Sob sua supervisão, a SEP espera os seguintes resultados ${ }^{46}$ :

“(a) Acompanhamento das informações periódicas e eventuais divulgadas ao mercado pelas companhias, verificando sua disponibilização oportuna e sua qualidade, de modo a possibilitar a tomada de decisão pelo investidor de forma consciente.

(b) Acompanhamento da atuação dos administradores e acionistas controladores das companhias, verificando a observância do respeito às leis e normas societárias e aos direitos dos acionistas, de modo a fortalecer a confiança dos investidores no mercado."

Do resultado do item "a", a superintendência espera os seguintes riscos:

“(1) não prestação ou atraso na entrega das informações periódicas por parte das companhias;

(2) não divulgação adequada, pelas companhias, seus administradores ou acionistas, de informações úteis, capazes de afetar as decisões de investimento e o exercício de direitos por parte dos acionistas minoritários; e

\footnotetext{
${ }^{44}$ Disponível em <http://www.cvm.gov.br/menu/acesso_informacao/planos/sbr/sbr.html . Acesso em 01 de junho de 2015.

${ }^{45}$ Disponível em <http://www.cvm.gov.br/menu/acesso_informacao/planos/sbr/sbr.html $\geq$. Acesso em 01 de junho de 2015.

${ }^{46}$ Disponível em <http://www.cvm.gov.br/menu/acesso_informacao/planos/sbr/sbr.html $\geq$. Acesso em 01 de junho de 2015.
} 
(3) elaboração e divulgação, pelas companhias, das informações econômico financeiras em desacordo com a regulamentação vigente e com as disposições estatutárias das sociedades."

Quanto ao resultado do item "b", a SEP entende que está sujeito à (4) existência de irregularidades nas propostas e decisões da administração, nas deliberações em assembleias gerais e na condução dos negócios por parte dos controladores e órgãos de administração. Para combater esse ponto, com seu Ofício Circular/CVM/SEP/N $02 / 15$, a SEP pôs em prática análise que contempla $100 \%$ das negociações realizadas por administradores, controladores, e pela própria companhia, no período de 15 dias anteriores à divulgação das informações contábeis trimestrais e anuais.

Conforme o Plano, os eventos de risco expostos foram elencados em função dos seguintes acontecimentos:

“a) Evento de Risco 1: percentual de não entrega ou entrega em atraso dos principais documentos periódicos, observado entre 2011 e 2014.

b) Evento de Risco 2: número de ofícios de acompanhamento enviados pela BM\&FBOVESPA e pela SEP e de Ofícios de Alerta e de recomendação, envolvendo divulgação de informações, documentos relativos às assembleias gerais e atualização do Formulário de Referência, enviados para companhias de cada grupo, desde 01.01.2011.

c) Evento de Risco 3: número de pareceres ressalvados emitidos pelo auditor independente para companhias de cada grupo, desde 01.01.2011.

d) Evento de Risco 4: número de Termos de Acusação, Ofícios de Alerta e Propostas de Instauração de Inquérito envolvendo empresas de cada grupo que tramitaram pela SEP, desde 2011."

\subsubsection{Ofícios de Alerta no caso concreto}

Como exposto, os Ofícios de Alerta são meios acautelatórios, quanto aos riscos de dano ao mercado. A CVM age preventivamente, ao invés de reativamente.

Por ser instrumento de prevenção, a emissão de Ofício de Alerta é feita sem a existência de dano ou prejuízo efetivos. Assim, não há de se falar em justa causa, essencial à instauração de Processo Administrativo Sancionador. 
Com atos de risco, a CVM notificará a sociedade, alertando para o ato de risco cometido e para que não haja repetição e dano ao mercado.

A autarquia deverá instaurar Processo Administrativo Sancionador caso o evento de risco se repita, o que configuraria justa causa.

Entretanto, não foi nesse sentido que atuou a SEP, no caso dos Processos Administrativos CVM n ${ }^{\circ}$ RJ2010/17202 e RJ2010/16884.

A proposta apresentada pela administração da Companhia enquadrava-se em dois pontos considerados de risco: (i) a não divulgação adequada de informações úteis, capazes de afetar as decisões de investimento e o exercício de direitos por parte dos acionistas minoritários e (ii) a existência de irregularidades nas propostas e decisões da administração, nas deliberações em assembleias gerais.

Por isso, a CVM encaminhou dois ofícios ao Bradesco, apontando o desrespeito à lei acionária e os riscos que isso poderia gerar. Contudo, a administração do Bradesco optou por dar continuidade à operação de aumento de capital nos mesmos moldes, transformando o risco em fato, em danos a seus próprios acionistas e à segurança do mercado de capitais.

Vale repisar que a própria SEP e o Colegiado da CVM, em diversas oportunidades, se mostraram contrários ao método da operação, que contrariava dispositivo legal. Mesmo assim, a SEP não entendeu haver desrespeito à lei ou má-fé administrativa suficientes para caracterizar a justa causa.

Sem justa causa, não haveria motivo para a instauração de um Processo Administrativo Sancionador, extinguindo-se o processo investigativo.

Mesmo com os dois ofícios que já tinham sido enviados, mesmo reconhecendo o desrespeito à lei, mesmo com o Colegiado entendendo haver irregularidades e mesmo com o Bradesco dando continuidade à operação, a SEP optou por extinguir o processo e enviar um Ofício de Alerta.

A diluição injustificada não era mais um risco. A prática não equitativa não era mais um risco. Eram fatos. A infração ao art. 170, Parágrafo $1^{\circ}$, inciso III, da Lei 6.404 era um fato. Mesmo assim, com fatos concretos e ausência de risco, a SEP optou pelo envio do Ofício de Alerta. 
Isso não nos parece certo. Não cabe à área técnica decidir se determinada ilegalidade é ou não merecedora de instauração de procedimento administrativo. Diante da infração concreta, é seu dever dar início a Processo Administrativo Sancionador. A opção da SEP de emitir um Ofício de Alerta apenas existirá diante de atos de risco ao mercado.

No presente caso, a SEP deveria ter iniciado um Processo Administrativo Sancionador. Caso o Colegiado viesse a concordar que não havia ilegalidade merecedora de sanção, ele poderia absolver o Bradesco. Contudo, não nos parece razoável que essa apreciação tenha sido afastada, mesmo diante dos elementos de autoria e materialidade do caso.

Por fim, não obstante o equívoco da opção pelo envio de Ofício de Alerta, é importante tratarmos da ausência de publicidade dada aos Ofícios de Alerta, a despeito de regra constitucionalmente enunciada.

Sobre esse ponto, discorreremos no Capítulo 7, a seguir. 


\section{A Problemática da falta de publicidade do Ofício de Alerta}

Como apontado pela Santa Fé, não houve publicação do Ofício de Alerta enviado ao Bradesco. Essa ausência de publicidade desrespeita o Art. 37, da Constituição Federal, que enuncia o princípio da publicidade aos atos praticados pela administração pública.

O princípio da publicidade é de extrema importância para o bom funcionamento da administração pública. É a melhor forma do povo se assegurar que os agentes administrativos e seus representantes estão agindo conforme o interesse público, sob pena de desvio de finalidade.

Assim, nas palavras de Carvalho Filho:

"As atividades administrativas são desenvolvidas pelo Estado para benefício da coletividade. Mesmo quando age em vista de algum interesse estatal imediato, o fim último de sua atuação deve ser voltado para o interesse público. E se, como visto, não estiver presente esse objetivo, a atuação estará inquinada de desvio de finalidade." ${ }^{\prime 7}$

No mesmo sentido enuncia José Afonso da Silva:

"A publicidade sempre foi tida como um princípio administrativo, porque se entende que o Poder Público, por ser público, deve agir com a maior transparência possível, a fim de que os administrados tenham, a toda hora, conhecimento do que os administradores estão fazendo. Especialmente exige-se que se publiquem atos que devam surtir efeitos externos, fora dos órgãos da Administração." ${ }^{48}$ (grifos do autor)

Resta claro que apenas a mais ampla divulgação dos atos administrativos

possibilita o controle e a devida legitimidade e eficiência dos atos dos agentes.

"É para observar esse princípio que os atos administrativos são publicados em órgãos de imprensa ou afixados em determinado local das repartições administrativas, ou, ainda, mais modernamente, divulgados por outros mecanismos integrantes da tecnologia da informação, como é o caso da Internet." ${ }^{49}$

Assim também enuncia Hely Lopes Meirelles:

"A publicidade, como princípio da administração pública, abrange toda atuação estatal, não só sob o aspecto de divulgação oficial de seu atos como também de propiciação de conhecimento da conduta interna de seus agentes." ${ }^{50}$

\footnotetext{
${ }^{47}$ Carvalho Filho, José dos Santos. Manual de direito administrativo. 25. ed. rev., ampl. e atual. até a Lei $n^{\circ}$ 12.587, de 3-1-2012 - São Paulo: Atlas, 2012, p. 32.

${ }^{48}$ Silva, José Afonso da. Curso de Direito Constitucional Positivo. 34. ed. rev. e atual. São Paulo: Malheiros, 2011.p. 670.

${ }^{49}$ Carvalho Filho, José dos Santos. Op. Cit. p. 25.

${ }^{50}$ Meirelles, Hely Lopes. Direito Administrativo Brasileiro. $37^{\mathrm{a}}$ ed. São Paulo: Malheiros Editores, 2010, p. 86 .
} 
Foi com esse intuito que atuou o legislador, com a edição da Lei $n^{\circ}$ 12.527. A promulgação da referida Lei deu concretude ao princípio da publicidade e tratou de regular tanto o direito à informação, quanto o direito de acesso a registros e informações nos órgãos públicos ${ }^{51}$.

Vale a pena pontuar que o referido princípio não é absoluto. A lei enuncia que, em alguns casos, deve-se ter sigilo. Entretanto, o caso em epígrafe não se encontra dentre estas situações. Sobre tais exceções, diz Alexandre Santos de Aragão ${ }^{52}$ :

“A Lei n. 12.527/2011 fixa parâmetros para que determinada informação seja classificada como sigilosa. Para determinar o grau de sigilo, deve ser considerada a gravidade do risco ou dano à segurança da sociedade e do Estado, bem como o prazo máximo da restrição, sempre utilizando o critério menos restritivo possível (art. 24, § $5^{\circ}$ ). Isso porque a Lei expressamente trata a publicidade como regra e o sigilo como exceção (art. $\left.3^{\circ}, \mathrm{I}\right) . "$

Mesmo assim, a SEP e o Colegiado da CVM indicaram que não existe nenhuma norma que obrigue as áreas técnicas a darem ou exigirem a publicidade dos Ofícios de Alerta enviados.

Por outro lado, sabe-se que a CVM vem discutindo a possibilidade de tornar os Ofícios de Alerta públicos. Embora, na época em que a Deliberação $n^{\circ}$ 542 estava sendo elaborada, o entendimento era pela não publicidade dos Ofícios, "Mas hoje o nosso entendimento é que seria muito bom divulgá-los, até mesmo para dar uma satisfação ao mercado" ${ }^{53}$, segundo Fernando Soares Vieira, Superintendente da SEP:

Nesse sentido, o Colegiado da CVM deu início à discussão sobre a elaboração de nova deliberação para revogar a Deliberação $n^{\circ} 542$, em sua

\footnotetext{
${ }^{51}$ Art. $1^{\circ}$ - "Esta Lei dispõe sobre os procedimentos a serem observados pela União, Estados, Distrito Federal e Municipios, com o fim de garantir o acesso a informações previsto no inciso XXXIII do art. 5o, no inciso II do $\S 3^{\circ}$ do art. 37 e no $\S 2^{\circ}$ do art. 216 da Constituição Federal.

Parágrafo único. Subordinam-se ao regime desta Lei:

(...)

II - as autarquias, as fundações públicas, as empresas públicas, as sociedades de economia mista e demais entidades controladas direta ou indiretamente pela União, Estados, Distrito Federal e Municípios."

${ }^{52}$ Aragão, Alexandre Santos de. Curso de direito administrativo. $2^{\text {a }}$ ed. rev. atual. e ampl. Rio de Janeiro: Forense, 2013. p. 180.

53 RAGAZZI, Ana Paula. CVM estuda tornar público alerta enviado a companhia. Valor Econômico, Rio de Janeiro, 11 jul. 2013.
} 
reunião de 28.01.2014. Essa nova deliberação traria a obrigatoriedade de publicação dos Ofícios de Alerta.

Esse mesmo movimento vem sendo observado nos Estados Unidos com as Deficiency Letters. Da mesma forma que os Ofícios de Alerta, as Deficiency Letters não são publicadas, conforme verificado no ComplianceAlert da SEC, de junho de $2007^{54}$. Entretanto, a SEC também enfrenta pressão do mercado para que estes documentos se tornem públicos. Como diz Andrea Kramer, diretora da asset Hamilton Lane: “acionistas estão pedindo, cada vez mais, por informações mais detalhadas, sendo as Deficiency Letters parte disto. Meu ponto de vista é que é muito difícil tomar uma decisão sobre um gestor sem essa informação" (tradução nossa) ${ }^{55}$.

\footnotetext{
${ }^{54}$ Disponível em <https://www.sec.gov/about/offices/ocie/complialert.htm>. Acesso em 01 de junho de 2015.

${ }^{55}$ WITKOWSKY, Chris. LPs want to see your SEC deficiency letter. PE Hub, 10 abr. 2014.
} 


\section{Conclusão}

O SBR criou a contenção mais eficaz de riscos e o Ofício de Alerta foi um importante passo para sua concretização.

Contudo, não entendemos ser razoável sua utilização fora de seu escopo, como ocorreu nos processos mencionados. Ele deve ser usado frente a ameaças e ameaças somente.

A CVM não deve optar por seu envio quando diante de um dano concretizado. Para esses casos, a legislação trouxe o instrumento do Processo Administrativo Sancionador. O Ofício de Alerta relaciona-se a riscos de danos ao mercado, mas mesma medida em que o Processo Administrativo Sancionador se relaciona à correção de danos já perpetrados.

A instauração de procedimento sancionador não é uma opção da autarquia. Como órgão regulador, é dever da CVM instaura-lo e punir os autores, caso se mostre necessário.

Mesmo assim, admitindo-se o envio de Ofício de Alerta, o caso concreto foi eivado de desrespeito ao princípio constitucional da publicidade dos atos da administração pública.

É direito dos acionistas a ampla divulgação dos atos incorridos pela sociedade, englobando, portanto, os Ofícios de Alerta.

Sem sua devida publicação, os acionistas ficam sem saber o que está acontecendo. Deixariam de saber que houve investigação da CVM, deixariam se saber que o procedimento adotado pela companhia foi ilegal. O acionista, mantido no escuro informacional, acabaria, sem saber, concordando ou não lutando contra as ilegalidades que venham a acontecer na companhia aberta.

O mercado de capitais depende do princípio da publicidade. Não nos parece razoável conceber que investidores venham a aplicar sua poupança em um mercado inseguro.

Muito embora o mercado de valores mobiliários seja um cenário de risco, o legislador deu instrumentos para que essa insegurança seja reduzida. A 
aplicação monetária deve ser cercada de confiança. Os investidores só terão sua hipossuficiência reduzida se munidos do maior aparato informacional possível.

Apenas com proteção e segurança que os acionistas poderão tomar boas decisões de investir. Apenas com seus investimentos que nosso mercado de capitais se expandirá. 


\section{Bibliografia}

ARAGÃO, Alexandre Santos de. Curso de direito administrativo. $2^{\mathrm{a}}$ ed. rev. atual. e ampl. Rio de Janeiro: Forense, 2013, 780 p.

BORBA, José Edwaldo Tavares. Direito societário - 13. ed. rev. e atual. - Rio de Janeiro: Renovar, 2012, 595 p.

CARVALHO FILHO, José dos Santos. Manual de direito administrativo. 25. ed. rev., ampl. e atual. até a Lei no 12.587, de 3-1-2012 - São Paulo: Atlas, 2012, $1.250 \mathrm{p}$.

COMISSÃO DE VALORES MOBILIÁRIOS. Processo Administrativo CVM n ${ }^{\circ}$ RJ2010/17202. Rel. Superintendência de Relações com Empresas, Rio de Janeiro, 16 dez. 2010.

. Processo Administrativo CVM n ${ }^{\circ}$ RJ2010/16884. Dir. Rel.

Otávio Yazbek, Rio de Janeiro, 17 dez. 2013.

Processo Administrativo CVM n ${ }^{\circ}$ RJ2013/11760. Rio de Janeiro, 28 jan. 2014 e 11 fev. 2014.

Disponível

em

http://www.cvm.gov.br/menu/acesso_informacao/planos/sbr/sbr.html. Acesso em 01 de junho de 2015.

EIZIRIK, Nelson; GAAL, Ariádna B.; PARENTE, Flávia; HENRIQUES, Marcus de Freitas. Mercado de capitais - regime jurídico. 3 ed. rev. e ampl. Rio de Janeiro: Renovar, 2011, 660 p. 
EIZIRIK, Nelson. Reforma das S/A e do Mercado de Capitais. Renovar: Rio de Janeiro, 1997, 420 p.

MEIRELLES, Hely Lopes. Direito Administrativo Brasileiro. $37^{a}$ ed. São Paulo: Malheiros Editores, 2010, 960 p.

SILVA, José Afonso da. Curso de Direito Constitucional Positivo. 34. ed. rev. e atual. São Paulo: Malheiros, 2011, 928 p.

DUBEUX, Julio Ramalho. A Comissão de Valores Mobiliários e os principais instrumentos regulatórios do mercado de capitais brasileiro. Porto Alegre: Sergio Antonio Fabris, 2006, 112 p.

SECURITIES AND EXCHANGE COMMISSION. Disponível em $<$ http://www.sec.gov/about/whatwedo.shtml\#laws>. Acesso em 28 de junho de 2014.

Disponível em <http://www.sec.gov/about/whatwedo.shtml\#.U4StjJRdVgw>. Acesso em 28 de junho de 2014.

Disponível em <http://www.sec.gov/ocie\#.U4abOZRdVgw>. Acesso em 28 de junho de 2014. $<$ http://www.sec.gov/about/whatwedo.shtml\#org>. Acesso em 01 de junho de 2015.

RAGAZZI, Ana Paula. CVM estuda tornar público alerta enviado a companhia. Valor Econômico, Rio de Janeiro, 11 jul. 2013. 
WITKOWSKY, Chris. LPs want to see your SEC deficiency letter. PE Hub, 10 abr. 2014 . 